\title{
Longevity of Apis mellifera workers fed on a diet incorporating entomopathogens
}

\author{
Longevidade de operárias de Apis mellifera \\ alimentadas com dieta incorporada com entomopatógenos
}

\author{
Fernanda Caroline Colombo ${ }^{1}$ (D), Rodrigo Mendes Antunes Maciel ${ }^{1}$ (D), Gabriela Libardoni ${ }^{1}$ (1), \\ Fernanda Raulino' ${ }^{1}$ (D), Everton Ricardi Lozano' ${ }^{1}$ (1), Fabiana Martins Costa Maia' ${ }^{1}$ (1), \\ Patrícia Franchi Freitas ${ }^{1}$ (), Pedro Manuel Oliveira Janeiro Neves ${ }^{2}$ (), Michele Potrich ${ }^{1}$ * (i)
}

\begin{abstract}
The present study had the objective of evaluating the longevity of $A$. mellifera workers fed on a diet incorporating commercial entomopathogens, Beauveria bassiana, and Bacillus thuringiensis. It also aimed at verifying possible morphological alterations in the midgut. To this purpose, the entomopathogens used were $B$. bassiana (Product A) $\left(5.0 \times 10^{11}\right.$ viable conidia. $\left.\mathrm{kg}^{-1}\right)$, B. thuringiensis (Product B) $\left(2.5 \times 10^{9}\right.$ viable spores. $\left.\mathrm{g}^{-1}\right)$, and $B$. thuringiensis (Product C) $\left(1.0 \times 10^{9}\right.$ viable spores. $\left.\mathrm{g}^{-1}\right)$; and two controls: T1: sterilized distilled water, and T2: sterilized distilled water + Tween $80^{\circledR}(0.01 \%)$. For the bioassays, $2 \mathrm{~mL}$ of each treatment were incorporated into Candy paste. For each treatment, 80 bees were individually in flat bottom glass tubes $(2.5 \mathrm{~cm} \varnothing)$ covered with voile, containing a piece of cotton soaked in water and Candy paste. These tubes were stored in a B.O.D (30 \pm $2{ }^{\circ}$ C, R.H $70 \% \pm 10 \%, 12 \mathrm{~h}$ ), and mortality was evaluated every six hours, for 10 days. Soon after verifying mortality, two bees per treatment were selected for the removal of their midgut. Midgut samples were processed using standard methodology for Scanning Electron Microscopy (SEM). It was verified that products $\mathrm{A}, \mathrm{B}$, and $\mathrm{C}$ reduced the longevity of bees when compared to $\mathrm{T} 1$ and $\mathrm{T} 2$ controls. In the qualitative analyses carried out using SEM, it was not possible to observe external or internal morphological alterations to midgut tissues. Although products A, B, and C cause a reduction in longevity, their presence was not verified when tissues were analyzed using SEM.
\end{abstract}

KEYWORDS: Africanized bee; biological insecticides; selectivity.

\begin{abstract}
RESUMO: No presente trabalho objetivou-se avaliar a longevidade de operárias de $A$. mellifera alimentadas com dieta incorporada com os entomopatógenos comerciais Beauveria bassiana e Bacillus thuringiensis, e verificar possíveis alterações morfológicas em seu mesêntero. Para isso, os entomopatógenos utilizados foram $B$. bassiana (Produto A) $\left(5,0 \times 10^{11}\right.$ conídios viáveis. $\left.\mathrm{kg}^{-1}\right), B$. thuringiensis (Produto B) $\left(2,5 \times 10^{9}\right.$ esporos viáveis. $\left.\mathrm{g}^{-1}\right), B$. thuringiensis (Produto $\mathrm{C}$ ) $\left(1,0 \times 10^{9}\right.$ esporos viáveis. $\left.\mathrm{g}^{-1}\right)$; e dois controles: T1: água destilada esterilizada e T2: água destilada esterilizada + Tween $80^{\circledR}(0,01 \%)$. Para os bioensaios, $2 \mathrm{~mL}$ de cada tratamento foram incorporados à pasta Cândi. Para cada tratamento, 80 abelhas foram acondicionadas, individualmente, em tubos de vidro de fundo chato $(2,5 \mathrm{~cm} \varnothing)$, cobertos com voile, contendo um pedaço de algodáo embebido em água e pasta Cândi. Os tubos contendo as abelhas foram acondicionados em B.O.D $\left(30 \pm 2^{\circ}\right.$ C, U.R. $70 \% \pm 10 \%, 12$ h), e a mortalidade foi avaliada a cada seis horas, durante 10 dias. Logo após a verificaçáo da mortalidade, foram separadas duas abelhas por tratamento para a retirada do mesêntero. Essas amostras foram processadas em metodologia padrão para Microscopia Eletrônica de Varredura (MEV). Verificou-se que os produtos A, B e Creduziram a longevidade das abelhas quando comparados aos controles $\mathrm{T} 1 \mathrm{e}$ T2. Nas análises qualitativas realizadas com MEV, não foi possível observar alteraçóes morfológicas externas ou internas nos tecidos do mesêntero. Apesar dos produtos A, B e C causarem reduçáo na longevidade, sua presença não foi verificada quando os tecidos foram analisados por MEV.
\end{abstract}

PALAVRAS-CHAVE: Abelha africanizada, inseticidas biológicos, seletividade.

\footnotetext{
'Universidade Tecnológica Federal do Paraná - Dois Vizinhos (PR), Brazil

${ }^{2}$ Universidade Estadual de Londrina - Londrina (PR), Brazil

*Corresponding author: profmichele@gmail.com

Received on: 06/02/2017. Accepted on: 07/29/2019
} 


\section{INTRODUCTION}

Apis mellifera L. bees are classified within the Hymenoptera order, Apidae family, in which approximately twenty thousand different species are known (RAMOS; CARVALHO, 2007). These organisms, especially worker bees, are important to ecosystems, because they are responsible for the pollination of vegetal species (IMPERATRIZ-FONSECA et al., 2012; JACK, 2015; MATUSIEWICZ et al., 2016), besides being producers of honey, propolis, royal jelly, wax, and apitoxin (COSTA-MAIA et al., 2010).

These specimens are present in greater quantity in the colony, and are also responsible for the collection of pollen and nectar, for feeding the queen, cleaning, and defending (GULLAN; CRANSTON, 2009; TAUTZ, 2010). At the time of nectar and pollen collection, worker bees can be exposed to microorganisms, carrying them back to the colony, where infection and dissemination can occur, seen that the colony is a conducive environment to the development of microorganisms. Thus, these factors can contribute to an increased mortality of colonies (D'URSO et al., 2017).

In recent decades, there has been a large-scale decline in the population of bees, known as colony collapse disorder, causing damage to agriculture (MESSAGE et al., 2011; JOHNSON et al., 2009). Various factors may be leading to this phenomenon. Among them, the wide scale usage of synthetic chemical products in pest control is highlighted (COSTAMAIA et al., 2010; KAPLAN, 2012; RUCKER; THURMAN, 2012), which is the most aggravating factor in Brazil.

Therefore, strategies to reduce or avoid the occurrence of this phenomenon are mandatory, such as, the use of biological control agents, like microbial insect control, which is considered less harmful due to its efficiency at lower concentrations and greater specificity, when compared to synthetic chemical insecticides (GUPTA; DIKSHIT, 2010; D'URSO et al., 2017). Among microbial control agents are entomopathogenic fungi and bacteria (ALVES, 1998), a type of control which has been used more often, especially given the preoccupation with health and environmental protection.

Although the use of biological control with entomopathogens has advantages in relation to synthetic chemicals, further studies must evaluate their possible effects on non-target organisms, and on $A$. mellifera bees in particular. Therefore, the objective of this study was to evaluate the longevity of $A$. mellifera workers fed with a diet incorporating commercial entomopathogens Beauveria bassiana (Bals.) Vuill, and Bacillus thuringiensis Berliner, and verify possible morphological alterations in their midgut under laboratory conditions.

\section{MATERIALS AND METHOD}

The experiments were carried out at Biological Control Laboratory (Laboratório de Controle Biológico) I and II, at Apiculture Teaching and Research Unit (Unidade de Ensino e Pesquisa Apicultura) (UNEPE-APICULTURE) of Universidade Tecnológica Federal do Paraná, Campus Dois Vizinhos (UTFPR-DV), and at Laboratory of Electron Microscopy and Microanalysis (Laboratório de Microscopia Eletrônica e Microanálise) (LMEM) of Universidade Estadual de Londrina (UEL).

\section{Obtaining entomopathogens}

Entomopathogens are formulated into commercial products: Product A (Cepa PL63), based on the Beauveria bassiana entomopathogenic fungus $\left(5.0 \times 10^{11}\right.$ viable conidia.kg-1); Product $\mathrm{B}$, with a formulation based on Bacillus thuringiensis, var. kurstaki, line HD-I, entomopathogenic bacteria $\left(2.5 \times 10^{9}\right.$ viable spores.g-1), at the concentration recommended by the manufacturer for Anticarsia gemmatalis (insect-pest of soybean crops), and Product $\mathrm{C}$, with a formulation based on B. thuringiensis aizawai GC-91 entomopathogenic bacteria $\left(1.0 \times 10^{9}\right.$ viable spores.g- 1$)$, at the concentration recommended by the manufacturer for Anticarsia gemmatalis (insect-pest of soybean crops), as in Table 1.

\section{Obtaining A. mellifera workers}

A. mellifera workers were obtained from six honeycombs, from Langstroth hives, for capped brood, from the Experimental Apiary of the Teaching and Research Unit (UNEPE) Apiculture of UTFPR-DV. The honeycombs were allocated in hives chosen based on quality and quantity of the queen's oviposition, and were given an artificial daily diet (isolated soya protein,

Table 1. Treatments and concentrations used in the bioassay.

\begin{tabular}{|c|c|}
\hline Treatments & Concentrations \\
\hline Sterilized distilled water & - \\
\hline Sterilized distilled water with Tween $80^{\circledR}(0.01 \%)$ & $10 \mu \mathrm{L} / 1000 \mathrm{~mL}$ of distilled water \\
\hline Beauveria bassiana (Product $\mathrm{A}$ ) & $1 \mathrm{~g}$ of the product. $100 \mathrm{~mL}^{-1}$ of sterilized distilled water with Tween $80^{\circ}(0.01 \%)$ \\
\hline Bacillus thuringiensis (Product B) & $0,5 \mathrm{~g}$ of the product. $100 \mathrm{~mL}^{-1}$ of sterilized distilled water \\
\hline Bacillus thuringiensis (Product C) & $0,5 \mathrm{~g}$ of the product. $100 \mathrm{~mL}^{-1}$ of sterilized distilled water \\
\hline
\end{tabular}


linseed oil, palm oil, beer yeast, sugar, honey, pollen, soya lecithin, and a nucleus of vitamins) until the beginning of oviposition. When the presence of one-day eggs was observed, feeding occurred three times a week, and a 21-day countdown was started (this is normally the time when workers emerge). On the $19^{\text {th }}$ day, the honeycombs were removed from the apiary, wrapped in Kraft paper bags $(60 \times 70 \mathrm{~cm}$ with $50 \mathrm{~mm}$ grammage), sealed, perforated, and transported to the Biological Control Laboratory II. The honeycombs were put in a heated B.O.D incubator $\left(30 \pm 2^{\circ} \mathrm{C}\right.$, R.H of $70 \pm 10 \%$, and a 12 -hour photophase) to simulate the environment of the hive of origin, until emergence, thereby obtaining workers with a standardized age.

\section{Effects of entomopathogens incorporated into the Candy paste on A. mellifera workers}

To perform the experiments, the recently emerged $A$. mellifera workers were individually transferred to flat bottom sterilized glass tubes $(10 \mathrm{~cm}$ long $\times 2.5 \mathrm{~cm} \varnothing)$, subsequently covered with voile cloth. A piece of cotton soaked in $2 \mathrm{~mL}$ of sterilized distilled water, and $5 \mathrm{~g}$ of Candy paste (icing sugar and honey) incorporated to the treatments was placed on the cloth. The treatments were: Sterilized distilled water, Sterilized distilled water with Tween $80^{\circ}(0.01 \%), B$. bassiana (Product A), B. thuringiensis (Product $\mathrm{B}$ ), and B. thuringiensis (Product C), as described in Table 1.

For all the treatments, $2 \mathrm{~mL}$ of control or entomopathogenic solutions were added to $100 \mathrm{~g}$ of Candy paste (100 g of icing sugar, and $20 \mathrm{~mL}$ of honey) to supply the workers. Each treatment consisted of 80 repetitions, whereby each glass tube containing a bee was considered a repetition. The tubes containing the workers were stored in a heated B.O.D incubator $\left(30 \pm 2^{\circ} \mathrm{C}\right.$, R.H of $70 \pm 10 \%$, and a 12 -hour photophase). The workers' longevity was evaluated every six hours, for 10 days.

For the bioassay with entomopathogens incorporated into Candy paste, an analysis of variance ANOVA was carried out, and the means were then compared to each other with ScottKnott test, at 95\% credibility level, on the Assistat program version 7.7 beta (SILVA, 2014).

Analysis of the midgut of $A$. mellifera using Scanning Electron Microscopy. After verifying bee mortality, two bees per treatment were randomly selected and separated for dissection and removal of the midgut, using metal tweezers, a scalpel, and a Stereoscopic Binocular Microscope [A.cietifica/ Edutec (model: 505A/80XB)]. At the time of dissection, the midgut received $1 \mathrm{~mL}$ of modified Karnovsky Fixative [Paraformaldahyde 3\%, Glutaraldahyde 3\% and Phosphate Buffer (PO4 0.1M)] to preserve them from possible decomposition. Midgut samples were set in modified Karnovsky Fixative overnight, and stored in a refrigerator $\left(4^{\circ} \mathrm{C}\right)$ at the Biological Control Laboratory II.
Subsequently, samples were taken to LMEM/UEL for washing in phosphate buffer $(3 \times 15$ minutes), fixing in an Osmium Tetroxide $1 \%(\mathrm{OsO} 4)$ solution for 1 hour, and then, another wash in phosphate buffer $(3 \times 15$ minutes). The material was then dehydrated in a battery of alcohol (alcohol $70 \%$ : $3 \times 10$ minutes, alcohol 80\%: $3 \times 10$ minutes, alcohol 90\%: $3 \times 10$ minutes, and alcohol 100\%: $4 \times 10$ minutes), and $\mathrm{CO}_{2}$ at Critical Point [BAL - TEC (model CPD 030)].

After dehydration, the samples were put on metal supports (stubs) containing silver glue, using a Stereoscopic Microscope, [LEICA model MZ6], and metal tweezers. The stubs with the samples were metalized with gold, using a Metallizer [BALTEC (model SCD - 050)], and then observed in a high vacuum of electron beam intensity, under Scanning Electron Microscopy. The images were captured through digital photos, and stored in a computer.

With the images, a qualitative analysis was carried out to verify the presence, or not, of entomopathogens in the samples, compared to the samples from the control.

\section{RESULTS AND DISCUSSION}

Effects of the entomopathogens, incorporated into Candy paste, on A. mellifera workers. The commercial product formulated based on $B$. bassiana (Product A) reduced the longevity of A. mellifera workers (60.45 hours) when compared to controls T1 and T2 (72.97 and 80.77 hours, respectively) (Table 2).

A similar effect was observed in other studies, in which the GHA isolate of $B$. bassiana entomopathogenic fungus, when tested for control of Varroa destructor Anderson and Trueman, and for selectivity of $A$. mellifera, in an experiment immersing mites in a solution of spores, caused a $40.83 \%$ reduction in the emergence of bees, and a mortality of $59.17 \%$, when the bees came into contact with mites contaminated with the fungus (HAMIDUZZAMAN et al., 2012).

On the other hand, isolates of $B$. bassiana, ARSEF 3769 (ARK), NY (NY, BB008, SCPFRC) and GHA, when tested with the contact method on the surface of canola leaves (Brassica napus L.) did not cause mortality in A. mellifera workers, and insects infected by the fungus were not observed (AL-MAZRA'AWI et al., 2006). Other biological parameters of $A$. mellifera were evaluated when in contact with B. bassiana, of which MEIKLE et al. (2007) verified that $B$. bassiana did not have an effect on the weight of the colony, weight of adult bees, or on honey production. The reduction in longevity of $A$. mellifera workers, after receiving a diet incorporating $B$. bassiana, may be related to the mode of infection, which is by contact. By feeding through the Candy paste, the workers may have entered into contact with conidia of the fungus, which forms a germinative tube when enters into contact with any part of the cuticle of the 
insect; the hyphae then crosses the tegument. After that, the fungus multiplies inside the insect, presenting hyphal mass in the hemocoel, initiating the process of colonization (ALVES, 1998; LAZZARINI, 2005).

The germination process may occur from 12 to 18 hours, and penetration of the conidia in the tegument takes approximately 12 hours. The fungus begins to produce and release toxic substances 30 hours after contact, which may cause stress or kill the insect. The insect presents itself as totally colonized 72 hours after inoculation, dying from lack of nutrients and the accumulation of toxic substances (ALVES, 1998). This may have been the cause of reduced longevity in A. mellifera workers, after the ingestion of Candy paste incorporated with $B$. bassiana in the present study.

As to bacteria, in this study, the commercial products formulated based on B. thuringiensis (products B and C) also reduced the longevity of the $A$. mellifera workers (64.12 and 62.47 hours, respectively) when compared to controls T1 and T2 (Table 2).

It has been verified in other studies that the $B$. thuringiensis entomopathogenic bacteria reduces survival of $A$. mellifera workers when incorporated into Candy paste (10 and $20 \mathrm{~g}$ of product $/ 60 \mathrm{~g}$ of Candy paste), causing a $100 \%$ mortality rate of the workers, 72 hours after ingestion (BRIGHENTI et al., 2007). In the same experiment, the authors verified that the mean longevity of bees was between 2.6 and 3.1 days when submitted to the concentrations of $B$. thuringiensis used $(0.25$, $0.5,1,2.5,5,10$, and $20 \mathrm{~g}$ ).

In this study, the two commercial products formulated based on B. thuringiensis bacteria caused a reduction in the longevity of the workers, after the ingestion of Candy paste incorporated with the entomopathogen. These workers presented a mean longevity of 64.12 hours (2.67 days), and 62.47 hours (2.60 days) (Products $B$ and $C$, respectively), similar results to those found by BRIGHENTI et al. (2007). It is possible that the results obtained in this study are related to the way the $B$. thuringiensis control agent acts. By ingesting the bacteria spores, they come into contact with the digestive tract of the insect, which has an alkaline pH (GALLO et al., 2002), and the crystals are thus solubilized, releasing protoxins, which transform into $\delta$-endotoxins in contact with cell proteases (ALVES, 1998; FIUZA, 2009). After, the crystals connect to receptors present in the cell membrane of the epithelium of the insect, causing perforations and then osmotic and ionic imbalance, disintegrating the cells and leading the insect to death by septicemia (ALVES, 1998; POLANCZYK; ALVES, 2003; FIUZA, 2009).

Although this is a valid hypothesis, the action of $B$. thuringiensis is commonly observed in less than 48 hours in other insects, like in lepidoptera (ALVES, 1998), which would be faster than that observed in the present study. DAI et al. (2012) also verified that the Cry1Ah toxin, arising from $B$. thuringiensis, when added to sugar syrup at different concentrations, does not alter survival, longevity, pollen consumption, or weight of the hypopharyngeal gland of $A$. mellifera ligustica, or Apis cerana cerana $\mathrm{F}$.

Analysis of the midgut of $A$. mellifera workers using scanning electron microscopy. After qualitative analysis of the images, it could be verified that $B$. bassiana entomopathogenic fungus did not cause external, or internal morphological alterations in the midgut tissues of $A$. mellifera bees, and was not present in the analyzed samples (Fig. 1A). The integrity of the midgut was also observed, with no signs of rupture or damage as a result of the effect of the product, when compared with controls T1 (Fig. 1B), and T2 (Fig. 1C).

In this study, the workers that ingested the Candy paste incorporated with $B$. bassiana possibly ingested the conidia of the fungus. However, these may not have penetrated the cuticle of the insect, and colonization may not have occurred as conidia and hyphae could not be verified in the analyzed midgut samples, which can be seen in Fig. 1A. Although it is not present in the analyzed midgut samples, the $B$. bassiana fungus reduced longevity of the $A$. mellifera workers, probably by producing toxins, such as beauvericin (ALVES, 1998), or the conidia may have caused stress to the bees, reducing their longevity. It was verified that $B$. thuringiensis entomopathogen did not cause external, or internal morphological alterations to the tissues of the midgut of $A$. mellifera workers, and was not present in the analyzed samples, despite reducing the longevity of bees. Integrity of the midgut was also observed,

Table 2. Longevity (in hours) ( \pm E.P.) of Apis mellifera workers after provision of Candy paste incorporated with entomopathogens. Temperature $30 \pm 2{ }^{\circ} \mathrm{C}, 12$-hour photophase, and R.H of $70 \pm 10 \%$. Universidade Tecnológica Federal do Paraná, Dois Vizinhos Campus, Paraná State, 2016.

\begin{tabular}{lcc}
\hline Treatments & Longevity (hours) & \multicolumn{2}{c}{ Longevity (days) } \\
\hline T1 (Sterilized distilled water) & $72.97 \pm 3.79 \mathrm{a}$ & 3.04 \\
\hline T2 (Sterilized distilled water with Tween $\left.80^{\circledR}(0.01 \%)\right)$ & $80.77 \pm 3.60 \mathrm{a}$ & 3.36 \\
\hline Beauveria bassiana (Product A) & $60.45 \pm 4.02 \mathrm{~b}$ & 2.51 \\
\hline Bacillus thuringiensis (Product B) & $64.12 \pm 3.99 \mathrm{~b}$ & 2.67 \\
\hline Bacillus thuringiensis (Product C) & $62.47 \pm 3.85 \mathrm{~b}$ & 2.60 \\
\hline p-value & $<0.01$ & \\
\hline
\end{tabular}



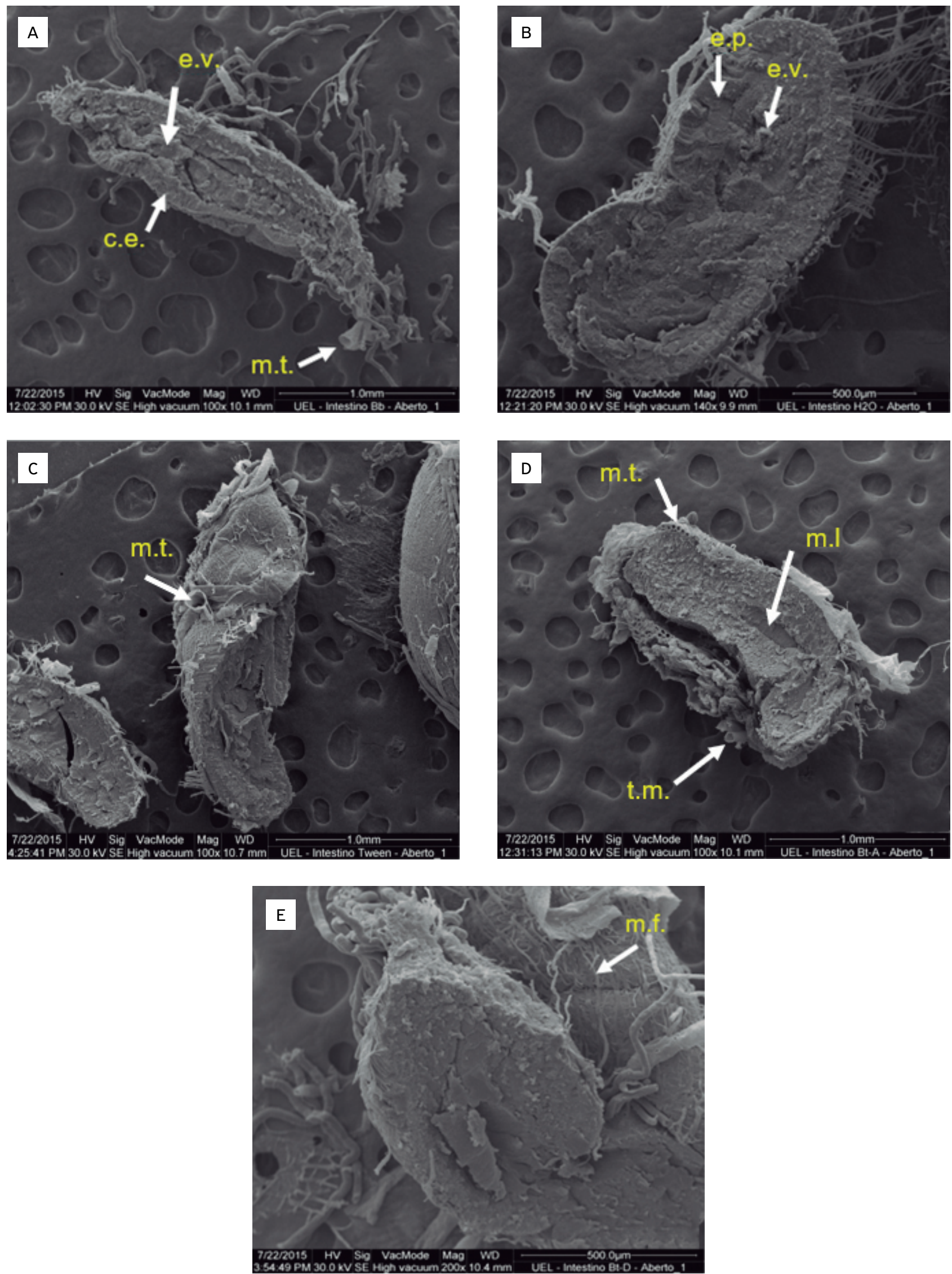

Figure 1. Scanning electron micrograph of the midgut of $A$. mellifera workers, after ingestion of Candy paste incorporated with (A) Beauveria bassiana (Product A); (B) Water control (T1); (C) Water control with Tween 80 (0.01\%), (T2); (D) B. thuringiensis (product B); (E) B. thuringiensis (product C). Midgut with longitudinal cuts. Cells of the epithelium (c.e.), Malpighi tubes (m.t.); epithelium of the ventricle (e.p.); esophagus valve (e.v.); muscular fibers (m.f.); and midgut lumen (m.l.). 
with no signs of rupture or damage because of the effect of products $\mathrm{B}$ (Fig. 1D), or C (Fig. 1E).

The cry $1 \mathrm{C}$ and cry $2 \mathrm{C}$ proteins of $B$. thuringiensis, incorporated into an artificial diet (royal jelly, glucose, fructose, distilled water, and yeast extract) supplied to the larvae of A. mellifera, did not provoke damage, visible under optic microscope, to the outer edges of the midgut of this insect (WANG et al., 2015).

Bacillus thuringiensis, at the field denominated concentrations $\left(100.0 \mathrm{~g} . \mathrm{hL}^{-1}\right)$, low concentration $\left(40.00 \mathrm{~g} . \mathrm{hL}^{-1}\right)$, and high concentration $\left(24,000.00\right.$ g.hL $\left.L^{-1}\right)$, provoked irregularities in the epithelium of the midgut of $A$. mellifera workers after 96 hours, whereby at the two highest concentrations these alterations were verified with scanning and transmission electron microscopy after the first 24 hours (D'URSO et al., 2017).

In the present study, the workers that ingested the diet incorporated with entomopathogenic $B$. thuringiensis possibly ingested the spores containing bacteria crystals, but the toxins may not have been activated by the $\mathrm{pH}$ of the digestive tract of these A. mellifera workers, as the proteases, which make the bacteria crystals toxic, have different activation conditions and may vary in insect species, according to eating habits, type of diet, and physical-chemical conditions of intestine lumen (ALVES, 1998). When the A. mellifera workers are fed artificially with honey and sugar, as in the present study, the $\mathrm{pH}$ of the digestive tract tends to diminish, as honey has low $\mathrm{pH}$, acidifying the $\mathrm{pH}$ of the midgut of the bees (COUTO; COUTO, 2002).

In all the midgut samples analyzed, it is possible to observe the presence of other microorganisms, like fungi and bacteria, which are probably from the insect's own digestive tract or are microorganism decomposers, resulting from the death of bees. In relation to the bacteria observed in the images, it is possible to confirm that they are not $B$. thuringiensis entomopathogenic bacteria, due to the difference in spore size.
The method and the time at which the entomopathogens are applied in the field may cause bees to be exposed to these products, albeit at lower quantities. Therefore, applications at times when the foraging rate is lower, like at the end of the afternoon, may diminish the bees' contact with the products. Another alternative for workers to avoid coming into contact with the entomopathogens is to close the hive during the period of application, performing artificial feeding during this period, or taking the hives to places at least $2.5 \mathrm{~km}$ away from where application of the products will be carried out.

Therefore, new studies, with different application methods are needed, so as to evaluate the effect of the entomopathogens tested. Among the different methods, spraying tests, A. mellifera contact and field tests can be cited.

\section{CONCLUSIONS}

In the tested formulations, B. bassiana and B. thuringiensis entomopathogens caused a reduction in the longevity of $A$. mellifera workers when incorporated in the bees' diet (Candy paste).

Despite the reduction in longevity, the integrity of the midgut could be observed, with no signs of ruptures caused by $B$. bassiana, or $B$. thuringiensis entomopathogens in the analyzed sample.

\section{ACKNOWLEDGMENTS}

We thank Araucária Foundation for supporting the project $(25.383-229 / 2013)$, and granting a fund to the first author. Prof. Dr. Célia Guadalupe. We also thank Laboratory Technician Mr. Osvaldo Capalbo for his guidance and assistance in conducting SEM.

\section{REFERENCES}

\begin{abstract}
AL-MAZRA'AWI M.S.; SHIPP, L.J.; BROADBENT, B.A.; KEVAN, P.G. Dissemination of Beauveria bassiana by honey bees (Hymenoptera: Apidae) for control of tarnished plant bug (Hemiptera: Miridae) on canola. Environmental Entomology, v.35, n.6, p.1569-1577, 2006. https://doi.org/10.1093/ee/35.6.1569
\end{abstract}

ALVES, S.B. Controle Microbiano de Insetos. Piracicaba: FEALQ, 1998. $1163 p$.

BRIGHENTI, D.M.; CARVALHO, C.F.; CARVALHO, G.A.; BRIGHENTI, C.R.; CARVALHO, S.M. Bioatividade do Bacillus thuringiensis var. kurstaki (Berliner, 1915) para adultos de Apis melifera Linnaeus, 1758 (Hymenoptera: Apidae). Ciênciae Agrotecnologia, v.31, n.2, p.279-289, 2007.http://dx.doi.org/10.1590/S1413-70542007000200003
COSTA-MAIA, F.M.; LINO-LOURENÇO, D.A.; TOLEDO, V.A. Aspectos econômicos e sustentáveis da polinização por abelhas. Sistemas de produção agropecuária (Ciências Agrárias, Animais e Floresta), v. 1, p.45-67, 2010.

COUTO, R.H.N.; COUTO, L.A. Apicultura: manejo e produtos. 2. ed. Jaboticabal: FUNEP, 2002. 193p.

D'URSO, V.; MAZZEO, G.; VACCALLUZZO, V.; SABELLA, G.; BUCCHIERI, F.; VISCUSO, R.; VITALE, D.G.M. Observations on midgut of Apis mellifera workers (Hymenoptera: Apoidea) under controlled acute exposures to a Bacillus thuringiensis-based biopesticide. Apidologie, v.48, n.1, p.51-62, 2017. https://doi. org/10.1007/s13592-016-0448-4 
DAI, P.; ZHOU, W.; ZHANG, J.; JIANG, W.; WANG, Q.; CUI, H.; SUN, J.; WU, Y.; ZHOU, T. The effects of Bt Cry 1 Ah toxin on worker honeybees (Apis mellifera ligustica and Apis cerana cerana). Apidologie, v.43, n.4, p.384-391, 2012. https://doi. org/10.1007/s13592-011-0103-z

FIUZA, L.M. Mecanismo de Ação de Bacillus thuringiensis. Revista Biotecnologia Ciência \& Desenvolvimento, v. 11 , n.38, p.32-25, 2009.

GALLO, D.; NAKANO, O.; NETO, S.S.; CARVALHO, R.P.L.; BAPTISTA G.C. de.; FILHO, E.B.; PARRA, J.R.P.; ZUCCHI, A.; ALVES, S.B.; VENDRAMIM, J.D.; MARCHINI, L.C.; LOPES, J.R.S.; OMOTO, C. 2002. Entomologia Agrícola. Piracicaba: FEALQ, 2002. 920p.

GULLAN, P.J.; CRANSTON, P.S. Os insetos: um resumo de entomologia. São Paulo: ROCA Ltda, 2009. 440p.

GUPTA, S.; DIKSHIT, A.K. Biopesticides: an ecofriendly approach for pest control. Journal of Biopesticides, v.3, n.esp. 1, p.186$188,2010$.

HAMIDUZZAMAN, M.M.; SINIA, A.; GUZMAN-NOVOA, E.; GOODWIN, P.H. Entomopathogenic fungi as potential biocontrol agents of the ecto-parasitic mite, Varroa destructor, and their effect on the immune response of honey bees (Apis mellifera L.). Journal of Invertebrate Pathology, v. 111 , n.3, p.237-243, 2012. https:// doi.org/10.1016/j.jip.2012.09.001

IMPERATRIZ-FONSECA, V.L.; CANHOS, D.A.L.; ALVES, D.A.; SARAIVA, A.M. Polinizadores no Brasil: contribuição e perspectivas para a biodiversidade, uso sustentável, conservação e serviços ambientais. São Paulo: EDUSP, 2012. 488p.

JACK, C. Colony Level Infection of Honey Bee Gut Pathogen, Nosema ceranae and Role of Pollen Nutrition in Nosema ceranae Infection and Bee Survival. 2015. Thesis (Master of Science in Horticulture) - Oregon State University, Oregon, 2015.

JOHNSON, R.M.; EVANS, J.D.; ROBINSON, G.E.; BERENBAUM, M.R. Changes in transcript abundance relating to colony collapse disorder in honey bees (Apis mellifera). Proceedings of the National Academy of Sciences, v.106, n.35, p.14790-14795, 2009. https://doi.org/10.1073/pnas.0906970106

KAPLAN, J.K. Colony collapse disorder: an incomplete puzzle. Agricultural Research, Washington, v.60, n.6, p.4-8, 2012.
LAZZARINI, G.M.J. Efeito da umidade sobre a germinação in vitro de Beauveria bassiana e Metarhizium anisopliae e atividade contra Triatoma infestans. Dissertação (Mestrado em Parasitologia) Instituto de Patologia Tropical e Saúde Pública, Universidade Federal de Goiás, 2005.

MATUSIEWICZ, M.; MARGAS, E.; MAZUREK, M.P.; WESOŁOWSKA, L.; BELTER, A.; SKUPINSKA, M. Viral infections of Apis mellifera: its importance, dynamics, diagnostics and treatment opportunities. Journal of Biotechnology, Computational Biology and Bionanotechnology, v.97, n.3, p.211-225, 2016. 10.5114/ bta.2016.62359

MEIKLE, W.G.; MERCADIER, G.; HOLST, N.; NANSEN, C.; GIROD, V. Impact of a treatment of Beauveria bassiana (Deuteromycota: Hyphomycetes) on honeybee (Apis mellifera) colony health and on Varroa destructor mites (Acari: Varroidae). Apidologie, v.39, n.2, p.247-259, 2007. https://doi.org/10.1051/apido:2007057

MESSAGE, D.; GUIDUGLI-LAZZARINI, K.R.; FREITAS, N.H.; SIMÕES, Z.L.; SILVA, I.C.; TEIXEIRA, É.W. Colapso de colônias de abelhas africanizadas Apis mellifera L. (Hymenoptera, Apidae) no Brasil. Revista de Educação Continuada em Medicina Veterinária e Zootecnia, v.9, n.3, p.59, 2011.

POLANCZYK, R.A.; ALVES, S.B. Bacillus thuringiensis: uma breve revisão. Agrociencia, v.7, n.2, p.1-10, 2003.

RAMOS, J.M.; CARVALHO, N.C. Estudo morfológico e biológico das fases de desenvolvimento de Apis mellifera. Revista Científica Eletrônica de Engenharia Florestal, v.6, n.10, p.1-21, 2007.

RUCKER, R.R.; THURMAN, W.N. Colony collapse disorder: the market response to bee disease. PERC Policy Series, v.50, p. 1-32, 2012.

SILVA, F. Assistat 7.7. Software Estatístico. Campina Grande, Paraíba, BR, 2014.

TAUTZ, J. O fenômeno das abelhas. Trad. Gerson R. Neumann. Porto Alegre: ARTMED, 2010. 288p.

WANG, Y.; LI, Y.; HUANGZ, Y.; CHEN, X.; ROMEIS, J.; DAI, P.; PENG $Y$. Toxicological, biochemical, and histopathological analysis demonstrating that Cry $1 \mathrm{C}$ and Cry2A are not toxic to larvae of the honeybee, Apis mellifera. Journal of Agricultural and Food Chemistry, v.63, n.27, p.6126-6132, 2015. https://doi. org/10.1021/acs.jafc.5b01662 